\title{
A HOME FOR PARAPLEGIC SOLDIERS
}

\author{
By Colonel A. S. Chahal, V.S.M., M.S., F.R.A.C.S. \\ Professor of Orthopaedics, Armed Forces Medical College, Pune, 4IIOOI India
}

\begin{abstract}
This paraplegic home provides a domicile for paraplegic and tetraplegic soldiers who either have no home of their own or cannot go there for social, economic, geographical or medical reasons. Free board and lodgings are provided for the inmates, who are encouraged to work in a sheltered workshop, enabling them to be usefully employed and to earn additional income.
\end{abstract}

Key words: Paraplegic home; Rehabilitation.

\section{History}

FEw paraplegics were alive I year after sustaining injury to the spinal cord during World War I. However, all this was to be transformed following the inauguration of the National Spinal Injuries Centre at Stoke Mandeville by Sir Ludwig Guttmann during World War II.

Following the Indo-Pakistani conflict in I97I, we experienced a sudden increase of admissions to our Spinal Cord Injury Centre, the average annual number being 55, of which 85 per cent were traumatic. As the survival rate improved (and the mortality fell to 2 per cent), we were confronted in I97I and 1972 with a group of several disabled ex-servicemen, who required urgent rehabilitation and Government aid-including the provision of tricycles, mattresses, wheelchairs etc., in addition to necessary alterations in their homes.

In spite of all of these measures, however, there were a number of patients who were unwilling to be discharged from hospital, for a variety of reasons. Some had no homes of their own or had elderly parents unable to provide help. Others, who belonged to the Himachal Kumaon Hills or Nepal, found it impossible to propel wheelchairs in mountainous areas. Rajput soldiers from Rajasthan could not push their wheelchairs in the sand of their villages. In addition, of course, there was a group subject to frequent urinary infection or recurrent pressure sores.

With improved care during this period, the tetraplegics also started thriving and struggled to compete with paraplegics in every possible way. All this evoked the sympathy and help of the authorities and philanthropists. A social worker, Mrs Mehru Bogga raised large funds and this present home was constructed in I 973 in nine acres of land adjacent to our hospital. The home was officially opened by the President of India in September 1974, when the first group of ten paraplegics and four tetraplegics was admitted.

By 1977 the home was occupied to its full capacity of 25, so another block for 32 single (and including married quarters for 4), was added in I978. Of these 30 are paraplegics and 17 tetraplegics. Table I shows the annual admission and discharge state.

As the present $6 \mathrm{I}$ beds are likely to be filled by 1983 , a further 30 single-bedded block and married quarters will be constructed, so that there should be Ioo beds available in 1984 . 
TABLE I

Bed Occupancy in P.P.W. Kirkee, Poona

\begin{tabular}{|c|c|c|c|c|}
\hline Year & Admission & Discharge & Death & Beds Occupied \\
\hline I974 & I I & I & - & IO \\
\hline 1975 & I0 & 2 & - & I 8 \\
\hline 1976 & 6 & 3 & I & 20 \\
\hline I977 & 7 & 4 & - & 23 \\
\hline I978 & 3 & 3 & I & 22 \\
\hline 1979 & IO & - & - & 32 \\
\hline 1980 & I3 & I & - & 44 \\
\hline I98I & 3 & - & - & 47 \\
\hline Total & 63 & I4 & 2 & 216 \\
\hline
\end{tabular}

\section{Lay-out of the Home}

\section{Living area}

This consists of 2-bedded or 4-bedded units with attached bathrooms with W.C., wash basin, together with hot and cold shower facilities. The doors are one metre in breadth with a single-leaf spring for automatic closure. The beds are provided with hoist pulleys and each inmate has his own wardrobe, dressingtable and bedside-table with locker.

\section{Seminar area}

This includes a dining-hall with an anteroom for television, radio and indoor games. The dining table is $30^{\prime \prime}$ high with clear leg space, thus enabling paraplegics to wheel their chairs under the table at meal times. The kitchen complex with pantry and stores caters for three principal meals each day and is run by a paraplegic patient with experience in catering.

\section{Physiotherapy hall}

The physiotherapy hall has full facilities for mat exercises, pulleys and weights, wheel, weight-lifting and parallel bars. Some paraplegics are able to lift $200 \mathrm{lbs}$ weight on a special bench press table. Tetraplegics undergo balancing exercises to maintain tone in their remaining muscles and to assist sitting-up in bed and in chairs. Every occupier is expected to report to the physiotherapist for 30 min every morning.

\section{Sheltered workshop}

All inmates are encouraged to work and to earn some money in addition to their pension. For example, two are working as clerks in neighbouring industry, one runs a cycle stand at the nearby railway station and a tetraplegic with an electric wheelchair manages a cycle shop, with 30 cycles on hire. The latter now employs one paraplegic to assist him with the accounts and book-keeping, together with an able-bodied mechanic for cycle repairs. The remainder work in the sheltered workshop at the home. Four, using a Bragma-punching machine, print name plates and numbers for industry. Others work as tailors, watch repairers and carry out radio repairs. Two tetraplegics paint greetings cards with their 
mouths (Table II). Although 90 per cent of those with paraplegia are working, we are facing the problem of keeping tetraplegics-who are mentally alert but physically unable to work-busy.

Sports

Around the home there are spacious lawns and sporting facilities such as a basketball ground (the first in Asia), and a 100-metre racing track with six lanes for use in wheelchair racing.

There is also javelin throwing, putting the shot and a discus throw. Indoor games such as table tennis, darts and chess are popular, and there is participation in tournaments. A swimming pool is being planned, but at present the nearest available pool is $5 \mathrm{kms}$ away.

\section{TABLE II}

Employment state

\begin{tabular}{lr}
\hline A. Paraplegics & \\
I. Employed in P.P.W. & 3 \\
2. Employed in industry & 2 \\
3. Self-employed & 6 \\
4. Sheltered workshop & I4 \\
\multicolumn{2}{c}{ Total } \\
B. Tetraplegics & 25 \\
I. Cycle shop & \\
2. Painting-Greetings cards & I \\
\multicolumn{2}{c}{ Total } \\
\hline
\end{tabular}

\section{Rehabilitation}

During the last 7 years, I4 patients (having been living in the home for 6-24 months), have been discharged to live with their families. Nine of these are self-employed and run small businesses, such as tea or stationery shops. Five are employed as telephone operators, tailors or radio technicians. Their stay in the home gave them the self-confidence needed to manage their own affairs and to achieve financial independence. Some used their time in the home to obtain vocational training and to raise funds for future business activities.

\section{Medical care}

Early detection of pressure sores with preventive measures has been helpful in promoting activity and avoiding prolonged hospitalisation. The rate of readmission has been 20 per cent, the reasons for this are shown in Table III. Patients on permanent catheter draining had their catheters changed with aseptic care once a week. One patient, with a perineal urethral fistula has been on this regime for the last io years. Those who are healthy are encouraged to visit their relations once a year, and families are encouraged to visit the home to stay for a 
few days with their relative, also once a year. Six married paraplegics are living with their families and two are working on the staff of the home. We have, of course encountered difficulties. One patient, a war casualty of I97I, developed chronic cystitis and a third degree reflux. He also had extensive pari-articular ossification and was not permitted to return home for 3 years. Later there were frequent readmissions for renal failure and, having insisted on leaving the home to return to his family, he unfortunately developed severe pyelonephritis and died.

\section{TABLE III}

Hospital readmission

\begin{tabular}{clc}
\hline Si No. & Nature of complication & No. of patients \\
I & Pressure sore & 2 \\
2 & Urinary infection & 3 \\
3 & Burns & I \\
4 & Respiratory infection & 2 \\
5 & Contusion/abrasion & I \\
Total & & 9 \\
\hline
\end{tabular}

\section{Conclusion}

The success of this home has encouraged the government to construct a similar home at Chandigarh in the north at a cost of Rs.30 lacs. This new home was opened in December 1978 and has accommodation for I4 paraplegics and eight tetraplegics.

\section{SUMMARY}

It has been demonstrated by Guttmann, Bedbrook and others that after initial treatment and rehabilitation has been carried out, a number of paraplegics and tetraplegics are still unsuitable for discharge home for many reasons. This fact has become especially true in India following the Indo-Pakistani conflict I97I. Therefore, a home adjacent to our hospital has been provided to deal with this problem. In this home, in addition to the usual rehabilitation, physiotherapy, bladder care etc., the main emphasis has been occupational. All patients who are able to are encouraged to follow an occupation of some sort, i.e., watch repairing, tailoring, radio repairs etc. Some live at the home, and go out to work, while others remain in a sheltered workshop.

This policy has not only promoted independence and occupational skills, but has also given patients the opportunity of accumulating funds to set themselves up later in business at home.

\section{Un Foyer pour Militaires Paraplegiques}

\section{RÉSUMÉ}

Il a été prouvé par Guttmann, Bedbrook et autres, qu'après le traitement initial et la réadaptation un certain nombres de paraplégiques et de tétraplégiques ne peuvent rentrer chez eux pour de nombreuses raisons. Ceci est particulièrement vrai aux Indes après le 
conflit Indo-Pakistanais en I97I. Pour cette raison un foyer a été établi à proximité de notre hôpital pour résoudre ce problème. Dans ce foyer, en plus des activités de réadaptation, kinésinthérapie, rééducation vésicale, ... . la principale activité est surtout de type occupationnel. Toutes les personnes capables de le faire sont encouragées à effectuer un travail tel que l'horlogerie, la couture, la réparation de radios, ...

Les uns vivent dans le foyer et prennent un travail à l'extérieur, d'autres exercent leur activité dans un atelier protégé.

Notre politique a été de promouvoir l'indépendance et l'habileté professionnelle et aussi de donner aux personnes handicapées l'opportunité d'épargner afin de pouvoir s'établir chez eux.

\section{ZUSAMMENFASSUNG}

Guttmann, Bedbrook und andere haben darauf hingewiesen, daß aus verschiedenen Gründen einige Tetra- und Paraplegiker nach Abschluß der Erstbehandlung und vollen Rehabilitation nicht nach Hause entlassen werden können. Diese Erfahrung wurde in Indien nach Abschluß des Konfliktes zwischen Indien und Pakistan in besonderem Maße bestätigt. Aus diesen Gründen haben wir in Verbindung mit unserem Krankenhaus ein Heim eingerichtet. Hier liegt das Schwergewicht neben den üblichen Rehabilitationsmaßnahmen, Krankengymnastik, Blasentraining usw. auf der beruflichen Tätigkeit. Alle Patienten, die dazu in der Lage sind, werden dazu angehalten, zu arbeiten. In Betracht kommen Uhrmacher, Schneider, Radioreparaturen usw. Einige leven im Heim und gehen außerhalb zur Arbeit, andere Arbeiten in einer beschützenden Werkstatt.

Hierdurch wird nicht nur die Unabhängigkeit und die Berufsausbildung gefördert, sondern die Patienten können so auch die finanzielle Grundlage schaffen um später zu Hause selbst eine berufliche Existenz zu begründen. 